Weronika Wojturska

Uniwersytet Warszawski

wwojturska@op.pl

Joanna Pawlak

Warszawski Uniwersytet Medyczny

sjoanna.pawlak@gmail.com

\title{
Zgoda pacjenta warunkiem sine qua non interwencji medycznej
}

\author{
Patient Consent as a Condition sine qua non Medical Intervention
}

\section{STRESZCZENIE}

Artykuł ma na celu przeprowadzenie kompleksowej analizy prawnej pojęcia zgody badanego na przeprowadzenie zabiegu medycznego w świetle orzecznictwa krajowego i poglądów doktryny, włączając w to problematykę wyrażenia aktu woli osób małoletnich. Koncepcja świadomej zgody świadczeniobiorcy funkcjonuje obecnie jako wyznacznik zakresu lekarskiej bądź pielęgniarskiej ingerencji, decydującej tak o jej legalności, jak i całokształcie relacji pacjenta z personelem medycznym. Syntetyczna wykładnia zagadnienia zwraca uwagę także na dylemat kolizji wartości pomiędzy działaniem lekarza w obronie życia i zdrowia pacjenta bez uzyskania przezeń zgody na zabieg a kwestią pogwałcenia prawa badanego do zachowania nietykalności. W świetle tego autorzy klarują przesłanki odpowiedzialności prawnej personelu medycznego na mocy art. 192 k.k.

Słowa kluczowe: prawa pacjenta; zgoda pacjenta; prawo do samostanowienia; nietykalność osobista; interwencja medyczna; odpowiedzialność karna; pacjent małoletni

\section{WSTĘP}

Wkroczenie w chronioną konstytucyjnie podmiotowość pacjenta przez podmiot udzielający świadczeń zdrowotnych w celu dopuszczenia do interwencji medycznej pociąga za sobą konieczność uzyskania uprzedniej zgody. Wynika to z faktu zagwarantowania $\mathrm{w}$ polskim porządku prawnym prawa do samostanowienia i ochrony integralności jednostki, podkreślając zarazem fundamentalną pozycję badanego 
w każdym systemie zdrowotnym ${ }^{1}$. Ponadto dobrowolne poddanie się interwencjom medycznym sprzyja umocnieniu relacji zaufania pomiędzy pacjentem a podmiotem udzielającym świadczenia jako warunku koniecznego dla zapewnienia prawidłowego toku postępowania leczniczego ${ }^{2}$. Realizowanie procesu leczenia powinno wiązać się ze znajomością praw pacjenta, określeniem granic interwencji medycznej (w tym granic prawnych), jak również z ponoszeniem odpowiedzialności za podejmowanie jakichkolwiek świadczeń zdrowotnych (w tym zabiegów leczniczych) z naruszeniem przepisów. Na pograniczu prawa i medycyny dochodzi do konfliktu dóbr chronionych, jakimi są z jednej strony życie i zdrowie, a z drugiej prawo do samostanowienia ${ }^{3}$.

Autorzy niniejszego artykułu podejmują się kompleksowej analizy prawnej pojęcia zgody badanego na przeprowadzenie zabiegu medycznego w świetle orzecznictwa krajowego i poglądów doktryny, włączając w to problematykę wyrażenia aktu woli osób małoletnich. Syntetyczna wykładnia pozwoli na podniesienie w niniejszym opracowaniu dylematu kolizji wartości pomiędzy działaniem lekarza w obronie życia i zdrowia pacjenta bez uzyskania przezeń zgody na zabieg a kwestią pogwałcenia prawa badanego do zachowania nietykalności.

\section{POJĘCIE ZGODY DETERMINANTEM PRAWIDŁOWEGO PRZEBIEGU PROCEDURY MEDYCZNEJ}

Zasada autonomii pacjenta jest jedną z naczelnych zasad udzielania świadczeń zdrowotnych (w tym wykonywania zabiegów leczniczych) i wywiera istotny wpływ na cały system prawa medycznego sensu largo ${ }^{4}$. Współczesne poglądy doktryny w sposób jednomyślny opowiadają się za przyjęciem w relacji pacjent - lekarz koncepcji zgody na przeprowadzenie procedury medycznej5. Konieczność uzyskania zezwolenia wynika z konstytucyjnej gwarancji poszanowania osoby ludzkiej, jej godności, nietykalności oraz prawa do samostanowienia i ochrony integralności. Obligatoryjność, jaką nakłada sformułowanie art. 41 ust. 1 Konstytucji RP': „Każdemu zapewnia się nietykalność osobistą" - jest przede wszystkim zagwarantowaniem możliwie jak największego bezpieczeństwa osobistego obywateli. Wykładnia

1 J. Przybylska, Cywilnoprawne aspekty instytucji zgody pacjenta na interwencje medyczna i jej definicja, „Monitor Prawniczy” 2003, nr 16, s. 14.

2 K. Zgryzek, Przymusowe umieszczenie w szpitalu psychiatrycznym na tle projektu ustawy o ochronie zdrowia psychicznego, [w:] Materiaty z VII Krajowej Konferencji Sekcji Psychiatrii Sadowej, Warszawa 1990.

3 A. Fiutak, Odpowiedzialność karna za wykonanie zabiegu leczniczego bez zgody pacjenta, Warszawa 2016, s. 19.

4 Ibidem.

5 A. Dudzińska, Zgoda na działanie medyczne, „Prokuratura i Prawo” 2009, nr 11, s. 69-79.

6 Konstytucja Rzeczypospolitej Polskiej z dnia 2 kwietnia 1997 r. (Dz.U. nr 78, poz. 483). 
przepisu wskazuje na zakaz jakiegokolwiek naruszenia w sferze fizycznej i psychicznej człowieka ${ }^{7}$. Sąd Najwyższy uchwałą z dnia 13 marca 1990 r. zdefiniował wolność osobistą jako „możliwość (niezależność, swobodę) podejmowania przez człowieka decyzji zgodnie z własną wolą" ". Kluczowe znaczenie dla autonomii pacjenta ma także brzmienie art. 47 Konstytucji RP. Zgodnie z nim „Każdy ma prawo do ochrony prawnej życia prywatnego, rodzinnego, czci i dobrego imienia oraz do decydowania o swoim życiu osobistym".

Jak słusznie podkreśla A. Kopff, jurystyczna ochrona życia prywatnego opowiada się za zapewnieniem każdemu człowiekowi perspektywy formowania życia w sposób niezależny ${ }^{10}$. Ze względu na potrzebę ochrony podmiotowości pacjenta obowiązuje dobrowolność udzielania świadczeń jako warunek sine qua non skutecznego procesu medycznego ${ }^{11}$. Przeprowadzenie zabiegu leczniczego każdorazowo wiąże się z naruszeniem nietykalności cielesnej pacjenta ${ }^{12}$. $Z$ tego powodu przeprowadzenie zabiegu wymaga uzyskania uprzedniej zgody pacjenta lub jego przedstawiciela ustawowego. Źródłem jego autonomii jest wolność człowieka rozumiana jako prawo do swobodnego decydowania o sobie ${ }^{13}$. Podstawową przesłanką skuteczności zgody jest wyrażenie jej przez podmiot posiadający pełną zdolność do czynności prawnych oraz świadomego formułowania oświadczeń woli. W tym miejscu niejako za wskazówkę interpretacyjną należy wskazać art. 16 ustawy z dnia 6 listopada 2008 r. o prawach pacjenta i rzeczniku praw pacjenta ${ }^{14}$ : „Pacjent ma prawo do wyrażenia zgody na udzielenie określonych świadczeń zdrowotnych lub odmowy takiej zgody, po uzyskaniu informacji w zakresie określonym w art. 9"15. Ponadto, zgodnie z art. 34 ust. 1 ustawy z dnia 5 grudnia 1996 r. o zawodach lekarza i lekarza dentysty ${ }^{16}$, aprobatę wyrażaną w przebiegu procesu leczenia można określić jako swobodnie podjętą decyzję pacjenta, jego przedstawiciela ustawowego lub opiekuna faktycznego (zgoda zastępcza) bądź wspólnej akceptacji pacjenta wraz z innymi podmiotami współdecydującymi (zgoda kumulatywna), po uprzednim zapoznaniu się z przystępną i rzetelną informacją na temat przeprowadzenia planowanej procedury oraz możliwych skutkach i powikłaniach.

7 B. Banaszak, Konstytucja Rzeczypospolitej Polskiej. Komentarz, Warszawa 2012, s. 222.

8 KZP 33/89, OSNKW 1990, nr 7-12, poz. 23.

9 Zob. A. Kobińska, Zakres autonomii pacjenta na przyktadzie niewyrażenia zgody na zastosowanie preparatu krwi podczas ewentualnej interwencji medycznej w bliżej nieokreślonej przyszłości, „Transformacje Prawa Prywatnego” 2006, nr 3-4, s. 39-40.

10 A. Kopff, Koncepcja praw do intymności i do prywatności życia osobistego (zagadnienia konstrukcyjne), „Studia Cywilistyczne” 1972, t. 20, s. 16.

11 K. Zgryzek, op. cit.

12 R.A. Stefański, Prawo karne materialne. Część szczególna, Warszawa 2009, s. 235.

13 A. Liszewska, Odpowiedzialność karna za błąd w sztuce lekarskiej, Kraków 1998, s. 95.

14 Dz.U. z 2017 r., poz. 1318, 1524.

15 M. Dercz, T. Rek, Ustawa o zakładach opieki zdrowotnej. Komentarz, Warszawa 2007, s. 127.

16 Dz.U. z 2018 r., poz. 617, 650, 697, dalej jako: u.z.l. 
Definicja zgody, według J. Przybylskiej ${ }^{17}$, zakłada obligatoryjność oświadczenia woli tylko jednej strony oraz podkreśla, iż jest to jednostronne odwołalne działanie prawne, natomiast według M. Świderskiej ten akt woli należy rozumieć jako swobodnie podjętą decyzję wyrażoną według norm dostępnych dla innych uczestników czynności medycznych $^{18}$. Zezwolenie na naruszenie swojej integralności fizycznej w określonym zakresie musi zostać wyrażone w sposób konkretny, szczegółowy oraz na każdorazowy rodzaj interwencji po uprzednim uzyskaniu informacji na temat samego zabiegu ${ }^{19}$. Tym samym pacjent w sposób zamierzony przyjmuje na siebie ryzyko następstw uprzednio sprecyzowanego świadczenia zdrowotnego, dając wiarę wykonania zabiegu z należytą starannością.

Ustawodawca krajowy nie sprecyzował kwestii formy zgody na zabieg medyczny. Stosuje się w tej sytuacji tzw. dowolność czynności prawnej zgodnie z art. 60 k.c., który stanowi: „Z zastrzeżeniem wyjątków w ustawie przewidzianych, wola osoby dokonującej czynności prawnej może być wyrażona przez każde zachowanie się tej osoby, które ujawnia jej wolę w sposób dostateczny, w tym również przez ujawnienie tej woli w postaci elektronicznej (oświadczenie woli)"20 . Świadczeniobiorca może - poza wyjątkami przewidzianymi w ustawie - w sposób dowolny wyrazić swoją wolę dotyczącą postępowania medycznego wobec jego osoby.

Dowolność co do formy daje możliwość wyrażenia zgody zwykłej i/lub pisemnej. Pierwsza odnosi się do uzewnętrznienia woli pacjenta ustnie lub w sposób niebudzący wątpliwości, co wówczas określa się jako zgodę per facta concludentia ${ }^{21}$. Przykładem tego może być odsłonięcie planowanego miejsca wkłucia. Odbieranie zgody przez personel medyczny może być wyrażone przez każdorazowe tego typu zachowanie pacjenta, które w kontekście sytuacyjnym nie budzi żadnych obiekcji co do zgodności z jego wolą. Zarówno dorozumiana, jak i ustna forma wyrażania przyzwolenia może być uznana za wystarczającą w przypadku, gdy ustawodawca nie przewiduje inaczej. Przywołując tezę wyroku Sądu Apelacyjnego w Lublinie z dnia 27 lutego 1991 r.: „Fakt braku dokumentu obejmującego zgodę pacjenta na dokonanie operacji jest nieistotny dla odpowiedzialności lekarzy, skoro zgoda niewątpliwie była. Zgoda jest bowiem aktem świadomości chorego, który może znaleźć na piśmie jedynie swe potwierdzenie" 22 - należy stwierdzić, że wymóg ten traktowany jest jedynie ad probationem. Nie zgadza się z tym M. Filar, twierdząc, iż powyższy

17 J. Przybylska, op. cit., s. 741.

${ }_{18}$ M. Świderska, Zgoda pacjenta na zabieg medyczny, Toruń 2007, s. 67-72.

${ }_{19} \mathrm{Na}$ podstawie definicji podanej przez A. Przyłuską-Fiszer (Etyczne problemy genetyki-zarys problematyki, „Prawo i Medycyna” 1999, nr 4, s. 43).

${ }^{20}$ Ustawa z dnia 23 kwietnia 1964 r. - Kodeks cywilny (Dz.U. z 2017 r., poz. 459, 933, 1132; Dz.U. z 2018 r., poz. 398, 650), dalej jako: k.c.

${ }^{21}$ S. Niemczyk, A. Łazarska, Materialnoprawne elementy aktu zgody pacjenta w ujęciu prawnym i medycznym, „Prawo i Medycyna” 2005, nr 2, s. 50-53.

22 I ACa 16/91, OSA 1991, nr 2, poz. 5. 
wymóg należy traktować ad solemnitatem, czyli w sposób przesądzający o prawnej skuteczności zgody ${ }^{23}$.

Szczególną formę uzyskania zgody - formę pisemną - ustawodawca przewidział w przypadku działań medycznych obarczonych zwiększonym ryzykiem wystąpienia powikłań (np. w przypadku przeprowadzenia zabiegu operacyjnego). W przypadku wyraźnego żądania zastosowania formy szczególnej dopuszczalne jest rozpoczęcie procedury $\mathrm{z}$ uwzględnieniem zgody udzielonej tylko w formie dorozumianej, jednakże może to pociągać za sobą skutki prawne w sytuacji, gdy pacjent $w$ przyszłości będzie dowodził, że taka zgoda nie miała miejsca. Brak formy pisemnej rodzi trudności natury dowodowej ${ }^{24}$. Kolejnym przykładem, w którym świadczeniodawca zobowiązany jest do uzyskania zgody w formie pisemnej, jest przyjęcie pacjenta do szpitala psychiatrycznego. Zgodnie z art. 78 k.c.: „Do zachowania pisemnej formy czynności prawnej wystarcza złożenie własnoręcznego podpisu na dokumencie obejmującym treść oświadczenia woli”. Jednocześnie należy podkreślić, że w tym szczególnym przypadku decyzja o pozostawieniu pacjenta musi być poprzedzona osobistym zbadaniem pacjenta i stwierdzeniem wskazań do przyjęcia na oddział zgodnie z art. 22 ust. 1 ustawy z dnia 19 sierpnia 1994 r. o ochronie zdrowia psychicznego ${ }^{25}$. W sytuacji, gdy osoba uprawniona do złożenia oświadczenia woli nie jest w stanie złożyć własnoręcznego podpisu na dokumencie, należy umożliwić złożenie go za pomocą tuszowego odciśnięcia palca na dokumencie. Dla zapewnienia najwyższej ochrony integralności jednostki przy tego rodzaju deklaracji, poza danymi personalnymi osoby składającej odcisk, należałoby wpisać dane osoby poświadczającej ważność dokumentu ${ }^{26}$.

Powyżej opisane przykłady wyrażania zgody nie dotyczą formy, jaką nakłada postanowienie wydane przez sąd opiekuńczy. Jest to swego rodzaju specyficzna forma, która zawsze ma moc wiążącą.

\section{CHARAKTER PRAWNY ZGODY PACJENTA MAŁOLETNIEGO}

Różnorodne świadczenia medyczne obligują do uzyskania zgody w odpowiedniej formie zarówno w przypadku osób dorosłych, jak i małoletnich. Jak już wcześniej zostało wspomniane, zgoda stanowi jednostronne, odwołalne działanie prawne o charakterze zbliżonym do oświadczenia woli, jednakże nie jest czynno-

${ }_{23}$ M. Filar, Lekarskie prawo karne, Kraków 2000, s. 275.

${ }_{24}$ M. Safjan, Prawo i medycyna. Ochrona praw jednostki a dylematy współczesnej medycyny, Warszawa 1998, s. 69.

25 Dz.U. z 2011 r., nr 231, poz. 1375 z późn. zm.

${ }^{26}$ M. Świderska, op. cit., s. 67-72. 
ścią prawną $\mathrm{W}$ sensie prawa cywilnego ${ }^{27}$. W związku z powyższym autorzy uznają za stosowne, iż zdolność ta jest niezależna od posiadania zdolności do czynności prawnych, jednakże kwestia ta nie jest w pełni uregulowana przez ustawodawcę. Odmienne stanowisko zajmuje T. Dukiet-Nagórska, która twierdzi, że przyzwolenie na interwencję medyczną może wyrazić tylko osoba posiadająca pełną zdolność do czynności prawnych ${ }^{28}$. Na potrzeby niniejszego artykułu wyeksponowano różne rodzaje przyzwolenia, które podmiot udzielający świadczeń musi otrzymać, w szczególności uwzględniając osoby małoletnie.

Definicja osoby małoletniej na gruncie prawa cywilnego nie została sprecyzowana w sposób jednoznaczny. Dla scharakteryzowania pojęcia możliwie najdokładniej przyjmuje się w doktrynie dwa kryteria - wiek oraz stan cywilny. Zgodnie $\mathrm{z}$ art. $10 \S 1$ k.c. za pełnoletniego uznaje się osobę, która ukończyła 18 lat. A contrario można wnioskować, że każdy, kto nie ukończył wskazanej granicy wieku, jest osobą małoletnią. Drugie kryterium, na podstawie którego określa się małoletność, zostało zawarte w art. $10 \S 2$ k.c., który stanowi, iż osoba małoletnia uzyskuje pełnoletność z chwilą zawarcia przez nią związku małżeńskiego. Należy nadmienić, że w przypadku jego unieważnienia dana osoba nie traci praw wynikających z osiągnięcia już pełnej zdolności do czynności prawnej. Jak donosi M. Safjan, faktyczna zdolność do wyrażania zgody jest zwrotem „,niedookreślonym”, mimo iż zgodnie z regulacjami art. 10 k.c. definicja pełnoletności wydaje się klarowna. Natomiast M. Świderska zwraca szczególną uwagę na fakt, iż z racji tego nieprecyzyjnego określenia istnieje zagrożenie arbitralności oceny predyspozycji pacjenta i jego kompetencji w stosunku do poszczególnych przypadków. Mając na uwadze postępowanie zgodne z przepisami prawa oraz kierując się dobrem pacjenta, w obecnej sytuacji należy odwołać się zarówno do przepisów dotyczących zgody, wad oświadczenia woli, jak i ugruntowanego na tym tle orzecznictwa ${ }^{29}$.

Powszechnie przyjmuje się, iż to pacjent samodzielnie wyraża zgodę na oferowane mu świadczenie zdrowotne. Dochodzi jednak czasami do sytuacji, kiedy decyzję taką podejmuje za pacjenta inna osoba lub instytucja ${ }^{30}$. Mając to na uwadze, warto wskazać na takie rodzaje zgody pacjenta, jak: zgoda właściwa, która w przypadku małoletniego za dolną granicę wieku stanowi 16 lat pod warunkiem bycia zdolnym do świadomego wyrażania oświadczeń woli, oraz zgoda zastępcza, wyrażana przez uprawniony do tego podmiot ${ }^{31}$. W zależności od okoliczności są to przedstawiciel ustawowy bądź sąd opiekuńczy. Przedstawiciel ustawowy

27 J. Przybylska, op. cit., s. 741.

28 T. Dukiet-Nagórska, Świadoma zgoda pacjenta w ustawodawstwie polskim, „Prawo i Medycyna" 2000, nr 6-7, s. 87.

${ }^{29}$ M. Świderska, op. cit., s. 67-72.

30 J. Siewiera, I. Dembowska, Zgoda pacjenta na zabieg medyczny, www.lexmedis.pl/?p=263 [dostęp: 10.05.2018].

31 K. Baron, Zgoda pacjenta, „Prokuratura i Prawo” 2010, nr 9, s. 49. 
wyraża zgodę w imieniu pacjenta małoletniego (dopóki nie ukończy on 16. roku życia). Właściwy opiekun udziela również pozwolenia w imieniu osoby całkowicie ubezwłasnowolnionej ${ }^{32}$. Obligatoryjność zgody zastępczej sądu opiekuńczego powstaje, gdy:

- pacjent małoletni lub niezdolny do samodzielnego wyrażenia zgody nie posiada przedstawiciela ustawowego bądź kontakt z nim nie jest możliwy,

- przedstawiciel ustawowy odmówił zgody na świadczenie zdrowotne proponowane przez lekarza (np. w sytuacji, gdy zachodzi konieczność transfuzji krwi u małoletniego, którego rodzice są świadkami Jehowy),

- pacjent małoletni (od ukończenia 16. roku życia), ubezwłasnowolniony, ze stwierdzoną chorobą psychiczną lub upośledzony umysłowo, lecz dysponujący dostatecznym rozeznaniem, sprzeciwia się czynnościom medycznym ${ }^{33}$.

Analizując poszczególne przypadki, należy wskazać na decydującą rolę, jaką odgrywa sąd, działając w charakterze rozjemcy wobec kolizji woli pacjenta z wolą przedstawiciela ustawowego bądź w razie rozbieżności intencji pacjenta $\mathrm{i}$ jego przedstawiciela ustawowego z jednej strony a koncepcją lekarzy co do zasadności zrealizowania zabiegu z drugiej. Nie sposób pominąć także zagadnienia zgody kumulatywnej (podwójnej), która odnosi się do przypadków ukończenia przez pacjenta małoletniego 16 lat. Dodatkowo, poza jego świadomie wyrażoną wolą, wymagana jest zgoda jego przedstawiciela ustawowego. Równoznacznie traktuje się pacjenta ubezwłasnowolnionego całkowicie, który jest w stanie z rozeznaniem wypowiedzieć się w sprawie badania oraz w okoliczności, gdy zachodzi konieczność przeprowadzenia interwencji o podwyższonym ryzyku w stosunku do osoby ubezwłasnowolnionej częściowo ${ }^{34}$. Nie sposób nie zgodzić się z A. Zollem, który zwraca uwagę na niejednoznaczność ustawodawcy w odniesieniu do niektórych unormowań wyłącznie w stosunku do pacjenta ubezwłasnowolnionego całkowicie, zaś innych - do pacjentów ubezwłasnowolnionych, bez ograniczenia do owego rodzaju ubezwłasnowolnienia. W tej materii niejasności zaleca on przyjąć, że we wszystkich tych okolicznościach chodzi tylko o chorego ubezwłasnowolnionego całkowicie. Na aprobatę zasługuje także wskazanie na jeszcze jedno uchybienie ustawodawcy wynikające $\mathrm{z}$ dosłownej interpretacji art. 32 ust. 4, gdzie podaje się, że zgoda kumulatywna jest obligatoryjna tylko do badań osoby całkowicie ubezwłasnowolnionej, która z rozeznaniem może wypowiedzieć swoją opinię. Osoba taka w opozycji do małoletniego, który ukończył 16 lat, nie ma możliwości wyrażenia swojej opinii w stosunku do innej niż badanie interwencji medycznej35.

${ }^{32}$ U. Drozdowska, W. Wojtal, Zgoda i informowanie pacjenta, Warszawa 2010, s. 39.

${ }^{33} \mathrm{~K}$. Sowa, Rodzaje i formy zgody pacjenta, www.infodent24.p1/lexdentpost/rodzaje-i-formy -zgody-pacjenta,1719.html [dostęp: 10.05.2018].

${ }_{34}$ M. Dercz, Dziecko - pacjent i świadczeniobiorca, LEX/el. 2015.

35 A. Zoll, Granice legalności zabiegu medycznego, „Prawo i Medycyna” 1999, nr 1, s. 38. 
Podsumowując, wyrażenie zgody przez pacjenta małoletniego na określone świadczenie zdrowotne jest niepodważalnie jego prawem. Zgodnie z zachowaniem tzw. modelu partnerskiego, w celu zwiększenia intensyfikacji procesu leczniczego lekarz bądź pielęgniarka powinni uszanować wolę wyrażaną przez nieletniego. Należy podkreślić, jak niekonsekwentnie określono charakter stosunku prawnego, gdy wola osoby nieposiadającej pełnej zdolności do czynności prawnych sprzeciwia się decyzji podjętej przez jej przedstawiciela ustawowego ${ }^{36}$. Choć w praktyce stanowi to pole do ingerencji sądu opiekuńczego, to autorzy pragną zasygnalizować istnienie potrzeby rozwiązania tej kwestii na poziomie ustawowym ${ }^{37}$.

\section{PRAWO DO SAMOSTANOWIENIA WOBEC OBOWIĄZKU OCHRONY ŻYCIA LUB ZDROWIA PACJENTA - PRZESŁANKI ODPOWIEDZIALNOŚCI KARNEJ}

Przestępstwo wykonania zabiegu bez zgody pacjenta ustawodawca zamieścił w rozdziale XXIII Kodeksu karnego ${ }^{38}$ zatytułowanym Przestepstwa przeciwko wolności, co wskazuje, że jego przedmiotem ochrony jest wolność. Pojęcie to uznaje się za podstawowe, niezbywalne i naturalne prawo jednostki ${ }^{39}$. Warto zauważyć, że wprowadzenie przepisu wiązało się z koniecznością przejścia z paternalistycznego do partnerskiego modelu relacji pacjent - lekarz, w którym to zgoda pacjenta stanowi umocowanie prawne do działania lekarza ${ }^{40}$. Regulacja ta pozostaje zgodna z tendencją przyznającą prymat zasadzie voluntas aegroti suprema lex (,wola chorego prawem najwyższym”) nad zasadą salus aegroti suprema lex (,dobro chorego prawem najwyższym”). Przedmiotem ochrony z art. 192 k.k. jest prawo pacjenta do samostanowienia w zakresie podjęcia decyzji lub odmowy poddania się zabiegowi leczniczemu, także w sytuacji, gdy zagrożone jest jego życie lub zdrowie ${ }^{41}$. Jak wskazuje Kodeks Etyki Lekarskiej, powołaniem lekarza jest ochrona życia i zdrowia ludzkiego, zapobieganie chorobom, leczenie chorych

${ }^{36}$ R. Kędziora, Problematyka zgody. Odpowiedzialność karna lekarza w zwiąku z wykonywaniem czynności medycznych, Warszawa 2009, s. 46.

37 T. Dukiet-Nagórska, op cit., s. 92.

${ }^{38}$ Ustawa z dnia 6 czerwca 1997 r. - Kodeks karny (t.j. Dz.U. z 2017 r., poz. 2204; Dz.U. z 2018 r., poz. 20, 305, 663), dalej jako: k.k.

39 B. Gronowska, Wolność i bezpieczeństwo osobiste w sprawach karnych w świetle standardów Rady Europy, Toruń 1996, s. 12-14.

${ }^{40}$ A. Fiutak, op. cit., s. 20.

${ }^{41}$ M. Mozgawa, M. Kanadys-Marko, Zabieg leczniczy bez zgody pacjenta, „Prokuratura i Prawo" 2004, nr 3, s. 26. 
oraz niesienie ulgi w cierpieniu ${ }^{42}$. W tym miejscu należy zwrócić uwagę na wyraźną sprzeczność pomiędzy istotą zawodu lekarskiego a gwarantowaną konstytucyjnie zasadą nietykalności osobistej.

W doktrynie wielokrotnie podnosi się fakt, iż dopuszczenie w sposób prawnie określony zabiegu bez zgody pacjenta nie oznacza, że uprawnia to do czynności wbrew zgodzie w razie sprzeciwu. Na aprobatę zasługuje pogląd wyrażony przez G. Rejmana, zdaniem którego podmiot przeprowadzający interwencję medyczną nie może skorzystać z instytucji stanu wyższej konieczności, ponieważ próba ocalenia cudzego dobra nie powinna mieć miejsca w przypadku sprzeciwu samego zainteresowanego ${ }^{43}$. Choć poświęcenie dobra w postaci prawa do samostanowienia dla ratowania życia i zdrowia z obiektywnego punktu widzenia wydaje się być „,społecznie opłacalne", to - jak wskazuje E. Zielińska - czyniłoby te uprawnienia pacjenta do autonomicznej decyzji w praktyce pozorne i iluzoryczne. Ponadto powodowałoby to ryzyko wystąpienia zjawiska ,równi pochyłej”, gdzie przymus leczenia stałby się w praktyce regułą, a nie wyjątkiem, co stwarzałoby poważne niebezpieczeństwo przedmiotowego traktowania życia i zdrowia pacjenta, a w rezultacie zaburzenia prawidłowego modelu partnerstwa. Co ważne, ratowanie cudzego dobra nie powinno mieć miejsca, gdy podmiot ratowanego dobra nie życzy sobie interwencji w to dobro, albowiem prawo karne nie przyjmuje zasady uszczęśliwiania ludzi wbrew ich woli4 ${ }^{44}$ Obrazem tak uzasadnionych przekonań jest kwestia dopuszczalności skracania życia. Lekarz z samej istoty zawodu zaufania publicznego może przeciwdziałać cierpieniu, jednak w sposób nieskutkujący przyspieszeniem śmierci osoby badanej. Stąd o ile eutanazja czynna uznawana jest za czyn bezprawny, o tyle w postaci biernej lekarz nie ma obowiązku przedłużania procesu umierania pacjenta żądającego zaprzestania działań leczniczych.

Autorzy pragną zwrócić uwagę także na swoistą lukę prawną w związku z brakiem uregulowania okoliczności, w których pacjent, będąc nieprzytomny, nie jest w stanie wyrazić zgody na zabieg, zaś lekarz uznaje za zasadną przesłankę zwłoki grożącej niebezpieczeństwem z art. 34 ust. 7 ustawa z dnia 5 grudnia 1996 r. o zawodach lekarza i lekarza dentysty ${ }^{45}$. Przykład ten uzasadnia postawioną przez autorów tezę dotyczącą wystąpienia sytuacji kolizyjnej, gdzie z jednej strony na lekarzu ciąży egzekwowany prawem obowiązek udzielenia pomocy osobie znajdującej się w niebezpieczeństwie, zaś z drugiej sankcjonowany karnie z art. 192 k.k. obowiązek uzyskania zgody na taki zabieg. W tej sytuacji, zdaniem M. Filara,

${ }^{42}$ Art. 2 ust. 1 Kodeksu Etyki Lekarskiej (tekst jednolity ze zmianami uchwalony przez III Krajowy Zjazd Lekarzy w Warszawie dnia 12-14 grudnia 1993 r., Warszawa 1994).

${ }^{43}$ G Rejman, Odpowiedzialność karna lekarza, Warszawa 1991, s. 51.

${ }^{44}$ E. Zielińska, Powinności lekarza w przypadku braku zgody na leczenie oraz wobec pacjenta w stanie terminalnym, „Prawo i Medycyna” 2000, nr 5, s. 81.

45 Dz.U. z 2018 r., poz. 617, 650, 697. 
wybór przez lekarza zastosowania metody o podwyższonym ryzyku jest chroniony kontratypem kolizji interesów jako szczególny rodzaj stanu wyższej konieczności z art. $26 \S 5$ k.k. ${ }^{46}$

Warto także wskazać na dwie ustawowo sprecyzowane sytuacje, w których interwencja lekarska ze względu na ryzyko pacjenta może mieć miejsce bez zgody. Pierwsza z nich dotyczy czynności podjętych w następstwie konieczności niezwłocznej pomocy lekarskiej, na które - ze względu na wiek czy stan zdrowia pacjent nie może wyrazić zgody i nie ma możliwości porozumienia się z jego przedstawicielem ustawowym lub opiekunem faktycznym (art. 31 ust. 1 u.z.l.). Decyzję w tym przedmiocie lekarz powinien skonsultować z innym lekarzem, a gdy jest to niemożliwe, należy przystąpić do czynności leczniczej, umieszczając stosowną wzmiankę w dokumentacji medycznej pacjenta.

Drugą z możliwych czynności określa art. 34 ust. 7 u.z.l., wskazując na sytuacje stwarzające podwyższone ryzyko, gdy zwłoka spowodowana postępowaniem w sprawie uzyskania zgody groziłaby pacjentowi niebezpieczeństwem utraty życia, ciężkiego uszkodzenia ciała lub ciężkiego rozstroju zdrowia. Przykładem tego jest wykonanie zabiegu operacyjnego. W takim przypadku lekarz ma obowiązek, o ile jest to możliwe, zasięgnąć opinii drugiego lekarza, w miarę możliwości tej samej specjalności, a o wykonywanych czynnościach niezwłocznie obowiązany jest zawiadomić przedstawiciela ustawowego, opiekuna faktycznego lub sąd opiekuńczy oraz dokonać odpowiedniej adnotacji w dokumentacji medycznej pacjenta.

W myśl art. 35 ust. 1 u.z.l. nie sposób nie wskazać także na sytuacje, w których po rozpoczęciu czynności leczniczej pojawią się okoliczności uzasadniające konieczność zmiany uprzednio uzgodnionego postępowania lekarskiego. Generalna zasada wskazuje, że pacjent musi wyrazić zgodę na rozszerzenie interwencji medycznej. Natomiast w sytuacji bezzwłoczności lekarz ma prawo, bez uzyskania tej zgody, podjąć decyzję o zmianie zakresu zabiegu bądź metody leczenia lub diagnostyki w sposób umożliwiający uwzględnienie tych okoliczności. Przywołując tezę wyroku Sądu Najwyższego z dnia 29 grudnia 1969 r.:

Jeżeli lekarz operujący stwierdzi po otwarciu jamy brzusznej inny stan rzeczy niż wynikał z badań klinicznych, może on w pewnych wypadkach przekroczyć zakres zgody na zabieg udzielonej przez pacjenta. Może to jednak nastąpić tylko w wypadkach szczególnych, gdy nieprzeprowadzenie koniecznego zabiegu groziłoby życiu pacjenta, albo gdy chodzi o nieznaczną a niezbędną korekturę projektowanego zabiegu ${ }^{47}$.

W odpowiedzi na to M. Sośniak podkreśla, że wystąpienie nowych powikłań podczas operacji rozszerza zgodę udzieloną na pierwotny zabieg tylko wówczas,

\footnotetext{
${ }^{46}$ M. Filar, op. cit., s. 256-257.

${ }^{47}$ II CR 551/69, OSPIKA 1970, nr 11, poz. 224.
} 
gdy podjęcie nowych czynności nie charakteryzuje się większym ryzykiem dla chorego. W przeciwnym wypadku działania te ulegają legalizacji wtedy, gdy zwłoka w podjęciu decyzji o poszerzeniu pola operacyjnego zagrażałaby pacjentowi niebezpieczeństwem, przy czym nie może dotyczyć to organów szczególnie ważnych ${ }^{48}$.

Za legalny należy uznać tylko taki zabieg medyczny, który został przeprowadzony lege artis w celu leczniczym i za uprzednią akceptacją ze strony badanego, chyba że nie była ona prawnie wymagana. Brak którejkolwiek z przesłanek stanowi podstawę kwalifikacji czynu jako występku zagrożonego alternatywnie karą grzywny, ograniczenia wolności lub pozbawienia wolności do lat 2. Warto zaznaczyć, że ze względu na wymiar górnej granicy przewidzianej kary - nieprzekraczającej 5 lat -istnieje możliwość warunkowego umorzenia postępowania karnego na okres próby, który wynosi od roku do 3 lat, a bieg rozpoczyna się od chwili uprawomocnienia się orzeczenia (art. $67 \S 1$ k.k.). Na kanwie orzecznictwa ${ }^{49}$ jest to dopuszczalne w sytuacji, gdy wina i społeczna szkodliwość czynu nie są znaczne, okoliczności jego popełnienia nie budzą wątpliwości, a postawa sprawcy niekaranego za przestępstwo umyślne, jego właściwości i warunki osobiste oraz dotychczasowy sposób życia uzasadniają przypuszczenie, że pomimo umorzenia postępowania będzie przestrzegał porządku prawnego, w szczególności nie popełni przestępstwa (art. $66 \S 1$ k.k.). Ponadto w okresie próby sprawca może zostać poddany pod dozór kuratora lub osoby godnej zaufania, stowarzyszenia, instytucji albo organizacji społecznej, do której działalności należy troska o wychowanie, zapobieganie demoralizacji lub pomoc skazanym (art. $67 \S 2$ k.k.), oraz może być zobowiązany do naprawienia szkody w całości albo w części, zadośćuczynienia za doznaną krzywdę bądź zapłaty nawiązki. Sprawca może również liczyć na ewentualne odstąpienie od wymierzenia kary, pod warunkiem że społeczna szkodliwość czynu nie jest znaczna, a sąd jednocześnie orzeka środek karny, przepadek lub środek kompensacyjny oraz uzna, iż cele kary zostaną w ten sposób spełnione (art. 59 k.k.). Przykładem jest sytuacja wykonania zabiegu leczniczego bez zgody pacjenta, ale w sposób zgodny ze sztuką medyczną oraz tylko wówczas, gdy pacjent nie poniósł uszczerbku na zdrowiu, a wręcz przeciwnie - zabieg przyczynił się do polepszenia jego stanu zdrowia ${ }^{50}$. Ponadto ściganie sprawcy przestępstwa następuje wyłącznie na wniosek pokrzywdzonego (art. 192 § 2 k.k.), co zdaniem R. Kubiaka przyczynia się do niskiego współczynnika stwierdzonych i wszczętych postępowań za czyn z art. 192 k.k., jak wynika z analizy statystyki zawartej w tabeli $1^{51}$.

${ }^{48}$ M. Sośniak, Cywilna odpowiedzialność lekarza, Warszawa 1968, s. 50-51.

49 Zob. uchwała SN z dnia 29 stycznia 1971 r., VI KZP 26/69, OSNKW 1971, nr 3, poz. 33; wyrok SN z dnia 9 stycznia 2002 r., III KKN 303/00, „Prokuratura i Prawo” 2003, nr 2, poz. 3; wyrok SN (7) z dnia 11 lipca 1985 r., RNw 17/85, OSNKW 1986, nr 3-4, poz. 18; wyrok SN z dnia 24 lutego 2005 r., V KK 435/04, „Prokuratura i Prawo” 2006, nr 1, poz. 2.

${ }^{50}$ A. Fiutak, op. cit., s. 386.

51 R. Kubiak, Prawo medyczne, Warszawa 2014, s. 448. 
Pobrane z czasopisma Studenckie Zeszyty Naukowe http://szn.umcs.pl

Data: 26/04/2023 14:44:24

140

Weronika Wojturska, Joanna Pawlak

Tabela 1. Liczba postępowań wszczętych i stwierdzonych z art. 192 k.k. w latach 2011-1016

\begin{tabular}{|l|c|c|}
\hline \multicolumn{1}{|c|}{ Rok } & Liczba postępowań wszczętych & Liczba przestępstw stwierdzonych \\
\hline 2016 & 9 & 1 \\
\hline 2015 & 1 & 0 \\
\hline 2014 & 2 & 2 \\
\hline 2013 & 5 & 0 \\
\hline 2012 & 6 & 1 \\
\hline 2011 & 6 & 3 \\
\hline
\end{tabular}

Źródło: http://statystyka.policja.pl/st/kodeks-karny/przestepstwa-przeciwko-4/63487,Zabieg-leczniczy-art-192.html [dostęp: 10.04.2018]

Należy zgodzić się z A. Fiutak, która upatruje przyczyn niskiego wskaźnika wszczęcia i prowadzenia postępowań w obawie pacjenta przed tzw. zemstą środowiska medycznego ${ }^{52}$. W szczególności ma to miejsce w środowiskach hermetycznych, takich jak małe obszary wiejskie czy miasteczka, gdzie pacjent, tudzież jego przedstawiciel, nie decydują się na złożenie wniosku w obawie przed odmową interwencji medycznej w sytuacji faktycznej potrzeby.

\section{PODSUMOWANIE}

Jednym z podstawowych praw pacjenta, które ma służyć ochronie autonomii jego woli, jest prawo do wyrażenia zgody na wykonanie określonej czynności medycznej. Świadoma zgoda świadczeniobiorcy funkcjonuje obecnie jako wyznacznik zakresu lekarskiej bądź pielęgniarskiej ingerencji, decydując tak o jej legalności, jak i całokształcie relacji pacjenta z personelem medycznym. Funkcjonująca w praktyce lekarskiej zasada wzajemnego zaufania nie może być zbyt daleko osadzona. Ustawowo zdrowie człowieka zostało zaliczone do jego dóbr osobistych i, poza wyjątkami, to chory podejmuje świadomą decyzję.

Autorzy w niniejszym artykule podjęli próbę wyeksponowania potrzeby udzielenia zgody przez pacjenta nie tylko posiadającego pełną zdolność do czynności prawnych, ale również osoby małoletniej, jako warunku sine qua non interwencji medycznej. Za swoistą lukę prawną należy uznać brak reglamentacji kwestii sprzeczności co do podjęcia decyzji przez pacjenta małoletniego w sposób odmienny od przedstawiciela ustawowego. Lekarz z racji zawodu zaufania publicznego ślubuje wierność i gotowość do ochrony życia i zdrowia drugiej osoby, czemu na przeszkodzie może stanąć sprzeciw ze strony pacjenta. Obrazuje to wyraźną sprzeczność pomiędzy istotą zawodu lekarskiego a gwarantowaną konstytucyjnie zasadą nietykalności osobistej. W przypadku braku zgody, w myśl prymatu zasady voluntas aegroti suprema lex, personel musi uszanować wolę pacjenta, chyba że

\footnotetext{
${ }_{52}$ A. Fiutak, op. cit., s. 413.
} 
zachodzą przesłanki ku temu, aby wykonać procedurę medyczną w sposób niezwłoczny z powodu zagrożenia życia pacjenta. Wówczas w innym trybie rozstrzyga się, czy doszło do naruszenia praw pacjenta, co z kolei implikuje odpowiedzialność karną z art. 192 k.k.

\section{BIBLIOGRAFIA}

Banaszak B., Konstytucja Rzeczypospolitej Polskiej. Komentarz, Warszawa 2012.

Baron K., Zgoda pacjenta, „Prokuratura i Prawo” 2010, nr 9.

Dercz M., Dziecko - pacjent i świadczeniobiorca, LEX/el. 2015.

Dercz M., Rek T., Ustawa o zaktadach opieki zdrowotnej. Komentarz, Warszawa 2007.

Drozdowska U., Wojtal W., Zgoda i informowanie pacjenta, Warszawa 2010.

Dudzińska A., Zgoda na działanie medyczne, „Prokuratura i Prawo” 2009, nr 11.

Dukiet-Nagórska T., Świadoma zgoda pacjenta w ustawodawstwie polskim, „Prawo i Medycyna” 2000, nr 6-7.

Filar M., Lekarskie prawo karne, Kraków 2000.

Fiutak A., Odpowiedzialność karna za wykonanie zabiegu leczniczego bez zgody pacjenta, Warszawa 2016.

Gronowska B., Wolność i bezpieczeństwo osobiste w sprawach karnych w świetle standardów Rady Europy, Toruń 1996.

http://statystyka.policja.pl/st/kodeks-karny/przestepstwa-przeciwko-4/63487,Zabieg-leczniczy -art-192.html [dostęp: 10.04.2018].

Kędziora R., Problematyka zgody. Odpowiedzialność karna lekarza w zwiąku z wykonywaniem czynności medycznych, Warszawa 2009.

Kobińska A., Zakres autonomii pacjenta na przykładzie niewyrażenia zgody na zastosowanie preparatu krwi podczas ewentualnej interwencji medycznej w bliżej nieokreślonej przyszłości, „Transformacje Prawa Prywatnego" 2006, nr 3-4.

Kodeks Etyki Lekarskiej. Tekst jednolity ze zmianami uchwalony przez III Krajowy Zjazd Lekarzy, Warszawa, 12-14 grudnia 1993 r., Warszawa 1994.

Konstytucja Rzeczypospolitej Polskiej z dnia 2 kwietnia 1997 r. (Dz.U. nr 78, poz. 483).

Kopff A., Koncepcja praw do intymności i do prywatności życia osobistego (zagadnienia konstrukcyjne), „Studia Cywilistyczne” 1972, t. 20.

Kubiak R., Prawo medyczne, Warszawa 2014.

Liszewska A., Odpowiedzialność karna za bład w sztuce lekarskiej, Kraków 1998.

Mozgawa M., Kanadys-Marko M., Zabieg leczniczy bez zgody pacjenta, „Prokuratura i Prawo” 2004, nr 3 .

Niemczyk S., Łazarska A., Materialnoprawne elementy aktu zgody pacjenta w ujęciu prawnym i medycznym, „Prawo i Medycyna” 2005, nr 2.

Przybylska J., Cywilnoprawne aspekty instytucji zgody pacjenta na interwencję medyczna i jej definicja, „Monitor Prawniczy” 2003, nr 16.

Przyłuska-Fiszer A., Etyczne problemy genetyki-zarys problematyki, „Prawo i Medycyna” 1999, nr 4.

Rejman G., Odpowiedzialność karna lekarza, Warszawa 1991.

Safjan M., Prawo i medycyna. Ochrona praw jednostki a dylematy wspótczesnej medycyny, Warszawa 1998.

Siewiera J., Dembowska I., Zgoda pacjenta na zabieg medyczny, www.lexmedis.pl/?p=263 [dostęp: 10.05.2018]. 
Sośniak M., Cywilna odpowiedzialność lekarza, Warszawa 1968.

Sowa K., Rodzaje i formy zgody pacjenta, www.infodent24.pl/lexdentpost/rodzaje-i-formy-zgody -pacjenta,1719.html [dostęp: 10.05.2018].

Stefański R.A., Prawo karne materialne. Część szczególna, Warszawa 2009.

Świderska M., Zgoda pacjenta na zabieg medyczny, Toruń 2007.

Uchwała SN z dnia 29 stycznia 1971 r., VI KZP 26/69, OSNKW 1971, nr 3, poz. 33.

Uchwała SN z dnia 13 marca 1990 r., KZP 33/89, OSNKW 1990, nr 7-12, poz. 23.

Ustawa z dnia 23 kwietnia 1964 r. - Kodeks cywilny (Dz.U. z 2017 r., poz. 459, 933, 1132; Dz.U. z 2018 r., poz. 398, 650).

Ustawa z dnia 19 sierpnia 1994 r. o ochronie zdrowia psychicznego (t.j. Dz.U. z 2011 r., nr 231, poz. 1375 ze zm.).

Ustawa z dnia 5 grudnia 1996 r. o zawodach lekarza i lekarza dentysty (Dz.U. z 2018 r., poz. 617, $650,697)$.

Ustawa z dnia 6 czerwca 1997 r. - Kodeks karny (t.j. Dz.U. z 2017 r., poz. 2204; Dz.U. z 2018 r., poz. 20, 305, 663).

Ustawa z dnia 6 listopada 2008 r. o prawach pacjenta i rzeczniku praw pacjenta (Dz.U. z 2017 r., poz. 1318,1524$)$.

Wyrok SA w Lublinie z dnia 27 lutego 1991 r., I ACa 16/91, OSA 1991, nr 2, poz. 5.

Wyrok SN z dnia 29 grudnia 1969 r., II CR 551/69, OSPIKA 1970, nr 11, poz. 224.

Wyrok SN (7) z dnia 11 lipca 1985 r., RNw 17/85, OSNKW 1986, nr 3-4, poz. 18.

Wyrok SN z dnia 9 stycznia 2002 r., III KKN 303/00, „Prokuratura i Prawo” 2003, nr 2, poz. 3.

Wyrok SN z dnia 24 lutego 2005 r., V KK 435/04, „Prokuratura i Prawo” 2006, nr 1, poz. 2.

Zgryzek K., Przymusowe umieszczenie w szpitalu psychiatrycznym na tle projektu ustawy o ochronie zdrowia psychicznego, [w:] Materiaty z VII Krajowej Konferencji Sekcji Psychiatrii Sądowej, Warszawa 1990.

Zielińska E., Powinności lekarza w przypadku braku zgody na leczenie oraz wobec pacjenta w stanie terminalnym, „Prawo i Medycyna” 2000, nr 5.

Zoll A., Granice legalności zabiegu medycznego, „Prawo i Medycyna” 1999, nr 1.

\section{SUMMARY}

The purpose of the article is to conduct a comprehensive legal analysis of the patient's consent to carry out a medical procedure in the light of national case-law and doctrinal views, including the issue of the act of will of minors. The concept of informed consent of the beneficiary has become a determinant of the scope of medical or nursing intervention, constituting both its legality and the overall relationship of the patient with the medical staff. The synthetic interpretation of the issue also draws attention to the dilemma of the collision of values between the doctor's action in the defense of the patient's life and health without obtaining consent to the confluence, and the issue of violation of the test's right to preservation of inviolability. In light of this, the authors clarify the premises of legal liability of medical staff under Article 192 of the Criminal Code.

Keywords: patient's rights; patient's consent; the right to self-determination; personal inviolability; medical intervention; criminal responsibility; minor patient 